\title{
In vitro multiplication and acclimatization of black galingale (Curcuma Aeruginosa Roxb.)
}

\author{
Nurul Khumaida*, Sintho Wahyuning Ardie, Adi Setiadi, Latifa Nur Artiningsih \\ Department of Agronomy and Horticulture, Faculty of Agriculture, Bogor Agricultural University (IPB), Bogor, Indonesia.
}

\begin{tabular}{l}
\hline ARTICLE INFO \\
\hline Received on: $26 / 01 / 2018$ \\
Accepted on: 04/08/2018 \\
Available online: $18 / 04 / 2019$
\end{tabular}

Key words:

Shoot, propagation, in vitro, BAP, IAA.

\begin{abstract}
Black galingale (Curcuma aeruginosa Roxb.) is an important medicinal plant that is widely distributed in South and South-east Asia; however, its utilities in Indonesia are still limited due to superior varieties and seedling availability. Micro-propagation could provide rapid and true to type seedlings to meet the black galingale demand. The objectives of this study were to develop the best in vitro medium composition for shoot multiplication and to compare the field growth of plants originated from the rhizome and in vitro plantlet. The in vitro experiment was arranged in a randomized complete block design with two factors and five replications. The first factor was BAP concentration consisted of $0,2,4,6$, and $8 \mathrm{mg} \mathrm{l}^{-1}$. The second factor was IAA concentration consisted of $0,0.5$, and $1.0 \mathrm{mg} \mathrm{l}^{-1}$. Our results showed that number of shoots, number of leaves, and plantlet height were significantly affected by the interaction of IAA and BAP. The highest number of shoots was obtained in the medium containing $6 \mathrm{mg} \mathrm{l}^{-1} \mathrm{BAP}$ with no IAA. The in vitro grown plantlets were acclimatized and grown in the field. The growth of these in vitro originated plants was compared with those propagated through the rhizome.
\end{abstract}

\section{INTRODUCTION}

Zingiberaceae family is a group of plants widely used as raw materials for traditional medicine (Harit et al., 2012), spices and herbs (Gowda et al., 2012), natural colorant for food and fabric (Behura et al., 2002; Velayudhan et al., 2012), food industry (Jan et al., 2012), and as insecticide (Damalas, 2011; Tavares et al., 2013). Curcuma genus is naturally spread in the tropics and subtropics, from India to Thailand, Indochina, Malaysia, Indonesia, to Northern Australia (Maknoi et al., 2005; Ding et al., 2011). More than 80 species from Curcuma genus are originated from Indomalayan region (Cousin et al., 2007).

Curcuma aeruginosa Roxb. (Zingiberaceae) or known as black galingale is widely spread in South-eastern Asia (Srivilai et al., 2011) and it is one of many medicinal plants that are available in Indonesia. This plant has been known and cultivated as a medicinal

\section{"Corresponding Author}

Nurul Khumaida, Department of Agronomy and Horticulture, Faculty of Agriculture, Bogor Agricultural University (IPB), Bogor, Indonesia. E-mail:nurul_khumaida@apps.ipb.ac.id plant in Malaysia, Cambodia, and Myanmar. Compared to other plants from genus Curcuma, black galingale has the distinct property that is its bluish rhizome (Nurcholis et al., 2016; Setiadi et al., 2017). Black galingale rhizome is used as raw material for traditional medicine because of its biochemical compounds, such as saponin, triterpenoid (Nurcholis et al., 2016), flavonoid, polyphenol, guaianin (Takano et al., 1995), and glycan (Ranjini and Vijayan, 2005). According to Nugrahaningtyas et al. (2005), essential oil of black galingale contains 1.8-sineol. Phytochemical research on black galingale rhizome found three sesquiterpene groups, which were identified as zedoarol, curcumenol, and isocurcumenol (Sukari et al., 2007), curcumin (Srivastava et al., 2006), aeruginon, and curcuminon are identified as distinct compounds of black galingale (Atun et al., 2012). Black galingale rhizome is used as traditional tonic and anti-inflammation (Reanmongkol et al., 2006) to relief cough, asthma, and skin diseases (Nasrullah et al., 2010), anti-microbial (Angel et al., 2012), anti-fungi (Srivastava et al., 2006), anti-oxidant (Choudhury et al., 2013; Nurcholis et al., 2015), and anti-androgen (Srivilai et al., 2011).

Multiplication of black galingale is usually achieved through asexual propagation using rhizome (Theanphong et al., 2010). Rhizome utilization as plant propagation material also 
has constriction, which takes a long time for mass propagation. Plant tissue culture is a technique to isolate a part from the plant, cell, tissue, or organ, and grow it in aseptic condition, controlled environment, and nutrition until new plants are formed (Hussain et al., 2012). Tissue culture technology had been applied in a broad scale, especially in plant propagation. Tissue culture has advantages such as more efficient, and propagules can be produced in high number and quality (Sama et al., 2015), and true-to-type (Hussain et al., 2012; Mohanty et al., 2011). Growth response and in vitro multiplication rate are different among plant species, even among genotypes within species. Several in vitro multiplication protocols have been reported on several Zingiberaceae family members. However, in vitro multiplication protocol development on black galingale is still limited. Therefore, best in vitro medium for in vitro multiplication for plant production is needed, as an alternative to produce high-quality propagule with distinct varieties.

\section{MATERIALS AND METHODS}

This research was conducted in Tissue Culture Laboratory, Department of Agronomy and Horticulture, Bogor Agricultural University. Rhizome was originated from Kendal, Central Java. Shoot from rhizome with the size of 1-2 cm was washed with flowing water for 30 minutes. Sterilization was conducted by submerging shoots in $20 \%(\mathrm{~m} / \mathrm{v})$ streptomycin sulphate and $80 \%$ $(\mathrm{m} / \mathrm{v})$ mancozeb for 12 hours, continued with rinsing the rhizome using sterilized distillate water. Sterilization then continued by submerging the explants with sodium hypochlorite $(\mathrm{NaOCl}) 0.5 \%$ and $1.0 \%$ for 5 and 10 minutes, respectively, inside the laminar air flow cabinet. The last sterilization step was the addition of $0.6 \mathrm{ml}$ povidone iodine $10 \%$ for 5 minutes. Explant was planted in precondition medium (medium without nutrition and growth regulator, MS0) and then kept in culture chamber for 2 weeks with 24 hours light and $23^{\circ} \mathrm{C}$ of chamber temperature. Subculture to MS0 medium was conducted 2 weeks after culture (WAC).

Research was arranged according to Completely Randomized Block Design (CRBD) with two factors. First factor was the concentration of benzylaminopurine (BAP) with five levels, which were $0,2,4,6$, and $8 \mathrm{mg} \mathrm{l}^{-1}$ and the second factor was IAA concentration with three levels, which were $0,0.5$, and 1.0 $\mathrm{mg} \mathrm{l}^{-1}$ with five replications, which made 75 experimental units. Each experimental unit contained three explants of black galingale shoots, so there were 225 plantlet bottles. Observations included contamination percentage, first shoot emergence, number of shoots per plantlet, explant height, and number of leaves per plantlet.

Acclimatization was conducted using compost and charcoal husk $(1: 1 \mathrm{v} / \mathrm{v})$ that had been sterilized using an autoclave for 45 minutes at $121^{\circ} \mathrm{C}$ as a medium. Addition of $20 \%(\mathrm{~m} / \mathrm{v})$ streptomycin sulphate and $80 \%(\mathrm{~m} / \mathrm{v})$ mancozeb with a dosage of $15 \mathrm{ml}$ per plants was conducted in early preparation of plant medium to prevent bacterial and fungal development. Before acclimatization, black galingale plantlets in bottles were kept in a chamber with room temperature for 24 hours. The variables observed at acclimatization were plant survival percentage, plant height, and number of leaves.

\section{RESULTS AND DISCUSSION}

Explant that has been planted in experimental medium showed shoot initiation at 2 WAC. Based on the explants observation, shoot growth occurred after the root formations. The first shoot emergence happened on medium with $6 \mathrm{mg} \mathrm{l}^{-1} \mathrm{BAP}$ (2 WAC), while the latest shoot emergence happened on explants that were cultured in the medium with IAA 0.5 and $1.0 \mathrm{mg} \mathrm{l}^{-1}$ (Fig. 1). Variance analysis showed that addition of BAP and IAA had a significant effect on first shoot emergence. Research using 6-Benzyladine (BA) on Zingiber officinale explants also showed a similar result, in which the shoot emergence was faster at 2 WAC with an additional BA (Rout et al., 2001). While research conducted by Behera et al. (2010) showed different results, the addition of BAP on Curcuma longa L. explants inducted slower shoot emergence at 12-16 WAC.

Shoot multiplication is a very important step for in vitro plant propagation. At this step, plantlet that produced more shoot and could acclimatize well to the field increasing number of plant material that can be planted in the field. Variance analysis showed that BAP and IAA concentration had a significant effect on number of shoots per explant. Addition of BAP at concentrations of 2, 4,6 , and $8 \mathrm{mg} \mathrm{l}^{-1}$ without auxin was able to induct more shoots compared to explants that were grown without growth regulator (Fig. 2). Research by Theanphong et al. (2010) on black galingale explant showed that medium without growth regulator is not able for shoot induction, contrary with this research where all explant planted on medium without growth regulator also able for shoot induction with a different number of shoots. Cytokinin in plant tissue culture is involved in cell division, shoot proliferation, and root growth inhibitions. This research was similar with Yaacob et al. (2014) that showed additional BAP could improve number of shoots in curcumin. The optimal medium for obtaining the highest number of shoot (3.38 shoots per explant) in black galingale is with BAP of $6 \mathrm{mg} \mathrm{l}^{-1}$. This result was higher compared to Rahayu and Adil (2012) on galingale which was two shoots per explant and Chong et al. (2012) on white galingale which was 1.7 shoots per explant. The result showed that BAP addition without auxin is effective enough to improve number of shoot in black galingale plantlet.

Analysis of variance showed that interaction between the concentration of BAP and IAA had a significant effect on number of leaves and plantlet height (Table 1). Highest average number of shoot was 6.25 leaves per plantlet in medium with 6 $\mathrm{mg} \mathrm{l}^{-1} \mathrm{BAP}+0 \mathrm{mg}^{-1}$ IAA. Lowest number of leaves obtained in plantlet with the medium of $0.5 \mathrm{mg} \mathrm{l}^{-1}$ IAA without BAP, 2.13 leaves per plantlet (Table 1).

Highest plantlet was $2.5 \mathrm{~cm}$, obtained in medium with $6 \mathrm{mg} \mathrm{l}^{-1} \mathrm{BAP}+0 \mathrm{mg} \mathrm{l}^{-1}$ IAA, while the shortest was $0.63 \mathrm{~cm}$ obtained in medium with $0 \mathrm{mg} \mathrm{l}^{-1} \mathrm{BAP}+1 \mathrm{mg} \mathrm{l}^{-1}$ IAA. Research conducted by Shukla et al. (2006) showed that plantlet height was between $3 \mathrm{~cm}$ on medium MS0 $+0 \mathrm{mg} \mathrm{l}^{-1} \mathrm{BAP}$ and $0.63 \mathrm{~cm}$ in the medium of $0 \mathrm{mg} \mathrm{l}^{-1} \mathrm{BAP}$.

Acclimatization is the last step of in vitro plant propagation before plantlet can be planted to field (Kumar and Rao, 2012). Acclimatization is conducted by removing plantlet from culture bottle to acclimatization medium with low light exposure and high humidity (Yahya et al., 2015). The success of acclimatization is depending on gradual acclimatization number and good seedling handling (Shahihnozzaman et al., 2013). Seedling size and roots differentiation must be considered for plantlet acclimatization (Hazarika, 2003). Black galingale plantlet 


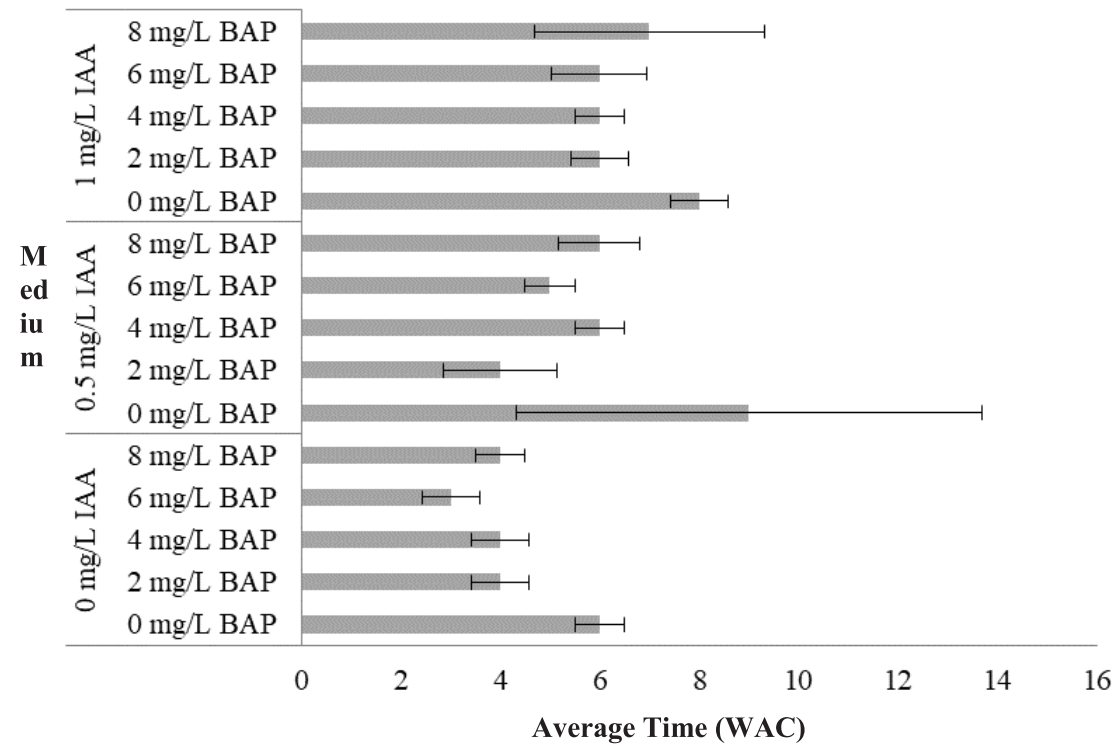

Figure 1. Average time of first shoot emergence of black galingale. Data are expressed as means $(n=5)$.

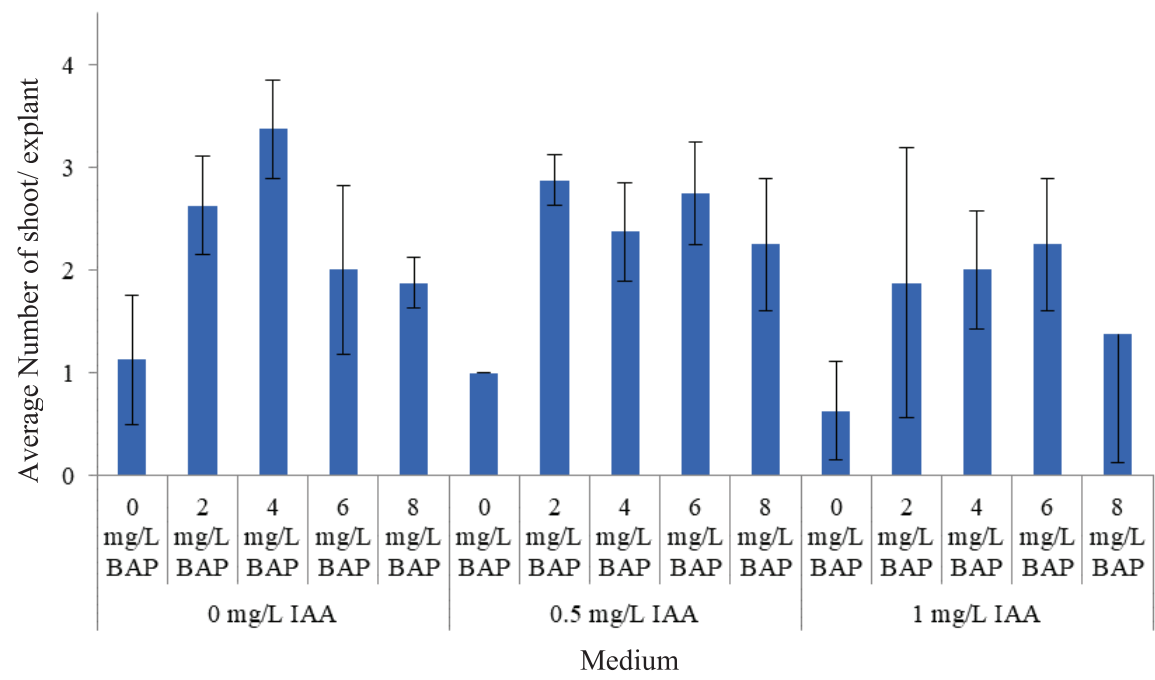

Figure 2. Average number of shoot of black galingale Kendal accession on several BAP and IAA concentration at 12 WAC. Data are expressed as means $(n=5)$.

Table 1. The effect of IAA and BAP concentration on average number of leaves and plantlet height of black galingale Kendal accession.

\begin{tabular}{|c|c|c|c|c|c|c|}
\hline \multirow{3}{*}{$\begin{array}{c}\text { BAP concentration } \\
\left(\mathrm{mg} \mathrm{l}^{-1}\right) \\
\end{array}$} & \multicolumn{6}{|c|}{ IAA concentration $\left(\mathrm{mg} \mathrm{l}^{-1}\right)$} \\
\hline & \multicolumn{3}{|c|}{ Average Number of leaves } & \multicolumn{3}{|c|}{ Average Plantlet height (cm) } \\
\hline & 0 & 0.5 & 1 & 0 & 0.5 & 1 \\
\hline 0 & $2.88 \mathrm{cA}$ & $2.13 \mathrm{cA}$ & $3.17 \mathrm{bA}$ & $1.80 \mathrm{bA}$ & $0.64 \mathrm{cB}$ & $0.63 \mathrm{bB}$ \\
\hline 2 & $3.88 \mathrm{abA}$ & $4.75 \mathrm{bA}$ & $3.50 \mathrm{bA}$ & $2.15 \mathrm{abA}$ & $2.39 \mathrm{aA}$ & 1.34abA \\
\hline 4 & $5.88 \mathrm{aA}$ & $3.50 \mathrm{bA}$ & $5.36 \mathrm{aA}$ & $1.79 \mathrm{bA}$ & $2.03 \mathrm{bA}$ & $2.05 \mathrm{aA}$ \\
\hline 6 & $4.75 \mathrm{abA}$ & $6.25 \mathrm{aA}$ & $2.75 \mathrm{bB}$ & $2.51 \mathrm{aA}$ & $1.73 \mathrm{bB}$ & 1.72abB \\
\hline 8 & $5.00 \mathrm{abA}$ & $4.63 \mathrm{bA}$ & $2.83 \mathrm{bB}$ & $1.93 \mathrm{abA}$ & $1.97 \mathrm{abA}$ & $0.70 \mathrm{bB}$ \\
\hline
\end{tabular}

Notes: Number followed by the same small letter at the same column of variable and number followed by the same capital letter at the same line means not significantly different based on DMRT at level of $\alpha=5 \%$. 


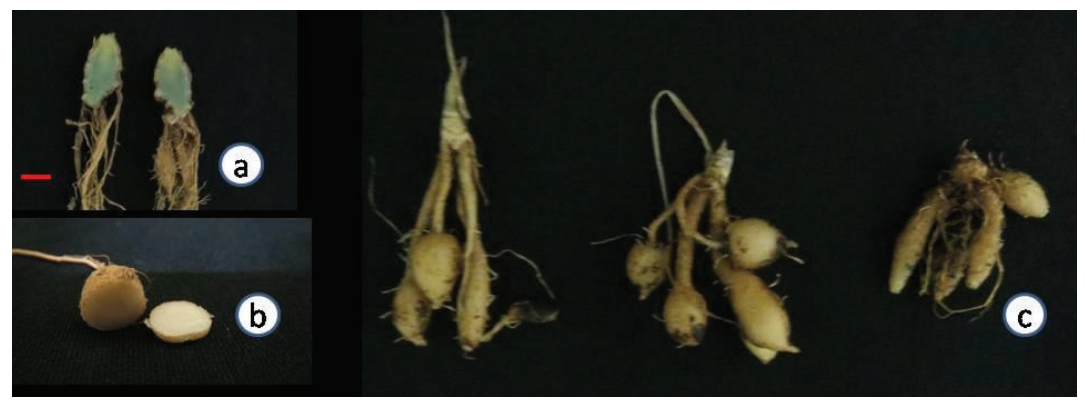

Figure 3. Black galingale rhizome from in vitro multiplication after acclimatization for 6 MAP. Cross section of mother rhizome (a), fleshy root (b), black galingale rhizome from in vitro multiplication (c), scale $=2 \mathrm{~cm}$.

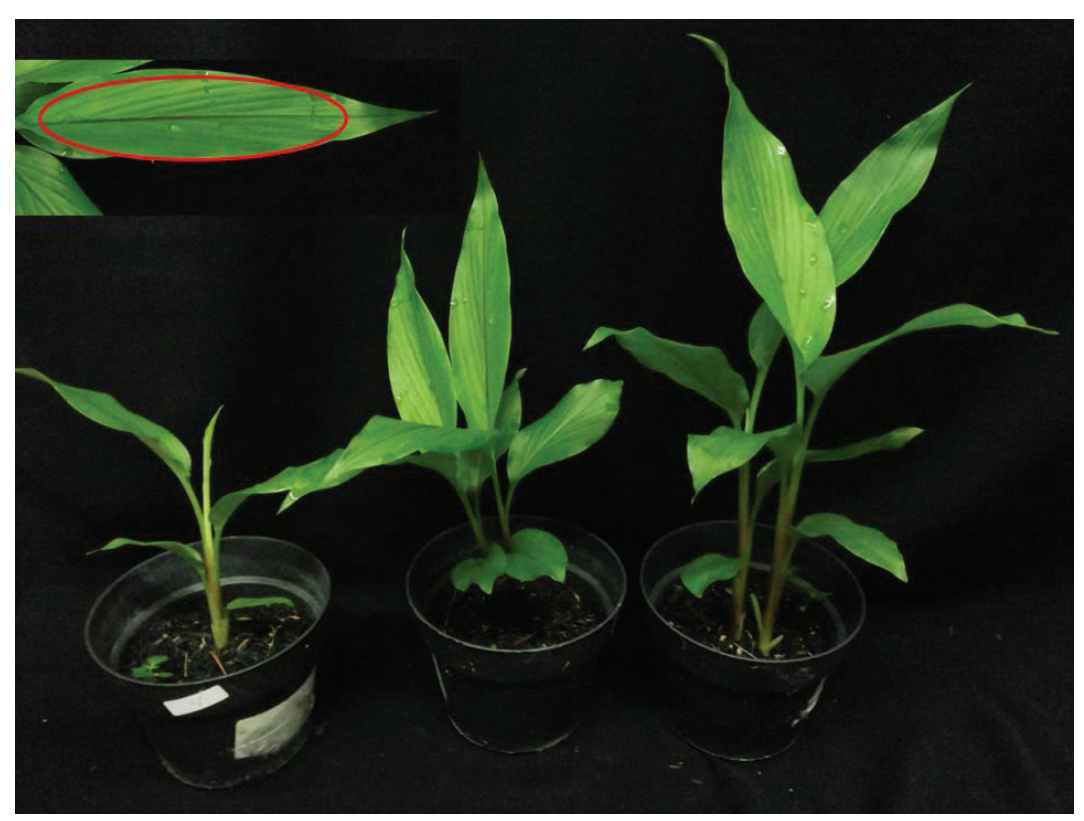

Figure 4. Black galingale performance that originated from in vitro multiplication. Notes: Red circles showed purple streak in leaf.

Table 2. Average number of leaves and plant height from acclimatization of black galingale Kendal accession plantlet at 2 WAC.

\begin{tabular}{|c|c|c|c|c|c|c|c|c|c|c|}
\hline \multirow{3}{*}{$\begin{array}{c}\text { IAA concen-tration } \\
\left(\mathrm{mg} \mathrm{l}^{-1}\right) \\
\end{array}$} & \multicolumn{10}{|c|}{ BAP concentration $\left(\mathrm{mg} \mathrm{l}^{-1}\right)$} \\
\hline & \multicolumn{5}{|c|}{ Average number of leaves } & \multicolumn{5}{|c|}{ Average plant height (cm) } \\
\hline & $\mathbf{0}$ & 2 & 4 & 6 & 8 & $\mathbf{0}$ & 2 & 4 & 6 & 8 \\
\hline 0 & $4.7 \pm 0.58$ & $6.7 \pm 1.16$ & $5.0 \pm 0.82$ & $6.3 \pm 2.31$ & $6.3 \pm 0.98$ & $9.8 \pm 1.46$ & $13.8 \pm 6.00$ & $12.3 \pm 4.27$ & $20.3 \pm 4.92$ & $12.2 \pm 3.76$ \\
\hline 0.5 & $6.3 \pm 0.58$ & $7.0 \pm 0.82$ & $3.3 \pm 0.96$ & $5.7 \pm 0.58$ & $4.7 \pm 0.58$ & $17.8 \pm 3.75$ & $17.7 \pm 2.76$ & $16.8 \pm 6.03$ & $14.0 \pm 4.00$ & $19.0 \pm 4.36$ \\
\hline 1 & $4.0 \pm 0.00$ & $4.7 \pm 1.53$ & $3.3 \pm 0.58$ & $5.7 \pm 1.15$ & $5.0 \pm 1.00$ & $9.2 \pm 1.56$ & $9.4 \pm 1.00$ & $11.3 \pm 1.21$ & $3.0 \pm 0.20$ & $3.8 \pm 0.35$ \\
\hline
\end{tabular}

Note: $* *$ significantly correlated at $\alpha=1 \%, *$ significantly correlated at $\alpha=5 \%$.

Table 3. Effect of fertilizer rate on the growth and productivity of black galingale originated from in vitro culture.

\begin{tabular}{lccccccccc}
\hline Fertilizer rate & $\begin{array}{c}\text { Plant height } \\
\mathbf{( c m )}\end{array}$ & $\begin{array}{c}\text { Stem diameter } \\
\mathbf{( c m )}\end{array}$ & Leaf number & $\begin{array}{c}\text { Leaf length } \\
\mathbf{( c m})\end{array}$ & $\begin{array}{c}\text { Leaf width } \\
\mathbf{( c m})\end{array}$ & $\begin{array}{c}\text { Rhizome fresh } \\
\text { weight } \mathbf{( g )}\end{array}$ & $\begin{array}{c}\text { Number } \\
\text { of mother } \\
\text { rhizome }\end{array}$ & $\begin{array}{c}\text { Number of } \\
\text { primary } \\
\text { rhizome }\end{array}$ & $\begin{array}{c}\text { Number of } \\
\text { secondary } \\
\text { rhizome }\end{array}$ \\
\hline P1 & $25.7 \pm 0.20$ & $0.76 \pm 0.00$ & $4.9 \pm 0.20$ & $11.9 \pm 8.28$ & $4.0 \pm 3.56$ & $16.2 \pm 17.71$ & $1.0 \pm 0.0$ & $4.2 \pm 2.9$ \\
P2 & $17.9 \pm 8.10$ & $0.4 \pm 0.01$ & $5.1 \pm 0.20$ & $9.2 \pm 5.10$ & $3.2 \pm 0.95$ & $13.0 \pm 11.23$ & $1.6 \pm 0.70$ & $4.8 \pm 3.1$ \\
P3 & $20.6 \pm 1.60$ & $0.5 \pm 0.14$ & $5.0 \pm 0.80$ & $10.1 \pm 2.28$ & $3.7 \pm 0.31$ & $6.2 \pm 3.37$ & $1.0 \pm 0.0$ & $2.5 \pm 0.2$ \\
Average & 21.42 & 0.56 & 5.00 & 10.4 & 3.6 & 11.8 & $3.3 \pm 1.3$ \\
\hline
\end{tabular}

Note: P1 $=20$ ton ha ${ }^{-1}$ of manure, P2 $=10$ ton ha ${ }^{-1}$ of manure, $200 \mathrm{~kg} \mathrm{ha}^{-1}$ Urea, $100 \mathrm{~kg} \mathrm{ha}^{-1} \mathrm{SP} 18,100 \mathrm{~kg} \mathrm{ha}^{-1} \mathrm{KCl}, \mathrm{P} 3=20 \mathrm{ton} \mathrm{ha}^{-1}$ of manure, $200 \mathrm{~kg} \mathrm{ha}^{-1} \mathrm{Urea}_{10} 100 \mathrm{~kg} \mathrm{ha}^{-1} \mathrm{SP} 18 \mathrm{and}^{100}$ $\mathrm{kg} \mathrm{ha}^{-1} \mathrm{KCl}$. 
that had poor root development also had poor growth that leads to plantlet death because of the bad rotting system which makes the plantlet cannot absorb the water nor nutrients from the medium. Only 40 black galingale plantlets had normal growth, while $25 \%$ of total plantlet had no growth until the end of observation. We assumed that the harsher environment in the experimental site (i.e., rocky and drier soils compared to the acclimatization conditions) caused the low living percentage of the transplanted seedlings.

Analysis of variance results showed that addition of BAP in the culture medium had no significant effect on number of leaves and plant height of black galingale after acclimatization. Highest number of leaves was shown in medium with $4 \mathrm{mg} \mathrm{l}^{-1} \mathrm{BAP}+0.5$ and $1 \mathrm{mg} \mathrm{l}^{-1}$ IAA. Plant height after in vitro acclimatization did not get affected by BAP and IAA concentration and shows various results on this character. Plant height observed was between 3.0 $\mathrm{cm}$ on medium $6 \mathrm{mg} \mathrm{l}^{-1} \mathrm{BAP}+1 \mathrm{mg} \mathrm{l}^{-1}$ IAA and 20.3 on medium $6 \mathrm{mg} \mathrm{l}^{-1} \mathrm{BAP}+0 \mathrm{mg} \mathrm{l}^{-1}$ IAA (Table 2).

Black galingale performance in acclimatization showed wide variation in plant height and number of leaves. At the same medium composition, treatment showed a different response on plant height and number of leaves. Purple shades could be observed on leaves in the medium with additional of $6 \mathrm{mg}^{-1} \mathrm{BAP}$ $+0 \mathrm{mg} \mathrm{l}^{-1}$ IAA at 4 MAP (month after planting).

Observation on black galingale rhizome from acclimatization was conducted after all leaves were fallen (6 MAP). Observation result showed that fleshy root was formed in rhizome with bigger size than the mother rhizome. Primary rhizome and secondary rhizome could not be found in every rhizome from acclimatized black galingale. Cross section of rhizome showed grayish color in mother rhizome and could not be found in the cross section of the fleshy root (Fig. 3a and b). Rhizome from acclimatized black galingale had smaller size and mass compared to rhizome from the field, a similar result to Salvi et al. (2002) in curcumin, where propagules from acclimatization had smaller rhizome size. Black galingale rhizome from acclimatization is shown in Figure 3c.

Harvested black galingale rhizome from in vitro propagation was replanted in medium with compost and charcoal husk $(1: 1 \mathrm{v} / \mathrm{v})$. The emergence of shoot from in vitro originated rhizome occurred at $1 \mathrm{MAP}$, and had similar performance with the previous acclimatized plant (Fig. 4). Therefore, acclimatized plantlet can be used for propagation propagules.

Adelberg et al. (2013) reported that nutrient affected the growth of turmeric during acclimatization; therefore, the black galingale mature rhizome and seedlings from in vitro culture were planted with different fertilizer rates in a separated experiment. Fertilizer rate significantly affects the growth and productivity of plant originated from in vitro culture. Manure application of 20 ton $\mathrm{ha}^{-1}$ resulted in higher plant, larger stem diameter, longer and wider leaf lobe, and higher rhizome fresh weight compared to those fertilized by manure and inorganic fertilizers (Table 3). $T$-test was performed to compare the growth and production of different planting material (rhizome versus seedlings from in vitro culture) and the data are presented in Table 4. Plants grown from in vitro culture showed lower living percentage $(54 \%)$ compared to those grown from the mature rhizome $(98 \%)$. The rhizome fresh weight of plants originated
Table 4. $T$-test results of several variables on black galingale plants from matured rhizome and acclimatized plantlet.

\begin{tabular}{lccc}
\hline \multicolumn{1}{c}{ Variables } & Rhizome & Plantlet & $\boldsymbol{t}$-test \\
\hline Percentage of growing plant (\%) & 98 & 54 & $* *$ \\
Number of leaves & 7.60 & 3.40 & $* *$ \\
Plant height $(\mathrm{cm})$ & 53.8 & 17.7 & $* *$ \\
Stem diameter (cm) & 1.20 & 0.50 & $* *$ \\
Leaf length (cm) & 32.2 & 10.3 & $* *$ \\
Leaf width (cm) & 10.9 & 3.40 & $* *$ \\
Fresh rhizome weight (gram) & 309.23 & 11.81 & $* *$ \\
Number of mother rhizome & 1.80 & 1.20 & $*$ \\
Number of primary rhizome & 6.50 & 3.80 & $* *$ \\
Number of secondary rhizome & 9.10 & 4.80 & $* *$ \\
\hline
\end{tabular}

from in vitro culture was also lower compared to those originated from the mature rhizome.

The photosynthetic organ of seedlings originated from in vitro culture might still not function properly. Naz et al. (2009) reported that the in vitro environment (i.e., supplemented nutrients and sucrose) lead to a limited photosynthetic cycle in the in vitro condition and caused morphological abnormalities on stomata and cuticle. The low photosynthetic capacity of the seedlings might cause low survival in the field. Seedlings might also have undeveloped rooting system during the in vitro culture as reported by Kozai et al. (2005) which also might lead to low survival in the field. In contrast, the rhizome is a well-developed planting material with energy storage which supports plant growth (Girija and Shree, 2014) and leads to a higher survival rate in the field.

The number of stomata on plant leaf is tightly related to leaf transpiration rate, where the higher transpiration rate means higher number of opening stomata, consequently allowing more $\mathrm{CO}_{2}$ absorption to be used for plant photosynthesis process (Lawson, 2009). The number of stomata on the lower part of black galingale leaf that originated from the matured rhizome and in vitro rhizome was not significantly different for fertilizer treatment. Average number of stomata on black galingale originated from matured rhizome was 108.4 per $\mathrm{mm}^{2}$, while the number of stomata originated from in vitro rhizome was 92.52 per $\mathrm{mm}^{2}$ (Table 5). Research conducted by Jadhao et al. (2015) on genus Curcuma showed that number of stomata was around 94-120 per $\mathrm{mm}^{2}$. The number of stomata on plant originated from matured rhizome and in vitro rhizome was not significantly different based on $t$-test (Table 4). The use of acclimatized plantlet as propagation propagules give the same potency as matured rhizome does.

Qualitative characters of acclimatized black galingale had no difference with its mother plants. On every observed plant, whether stem or rhizome vegetative characters had the same character with the mother plants, such as the presence of purple streak on the leaves and grayish white color of the rhizome (Table 6). The presence of purple streak in black galingale leaves can be observed on the fourth leaves (Fig. 4). However, this result also in accordance with Setiadi et al. (2017) research that conducted characterization on the morphology of several black galingale accession in Indonesia. 
Table 5. Number of Curcuma aeruginosa Roxb. stomata in plant originated from matured rhizome and acclimatized plantlet with different fertilizer rates (6 MAP).

\begin{tabular}{lcc}
\hline \multirow{2}{*}{ Fertilizer Rate } & \multicolumn{2}{c}{ Number of stomata $\left(\right.$ per $\left.\mathbf{~ m m}^{2}\right)$} \\
\cline { 2 - 3 } & Rhizome & Plantlet \\
\hline P1 & $109.6 \pm 23.4$ & $73.89 \pm 0.0$ \\
P2 & $110.4 \pm 83.3$ & $89.87 \pm 1.7$ \\
P3 & $105.3 \pm 11.5$ & $113.80 \pm 8.4$ \\
Average & 108.4 & 92.52 \\
\hline
\end{tabular}

Notes: $\mathrm{P} 1=20$ ton ha ${ }^{-1}$ manure, $\mathrm{P} 2=10$ ton ha ${ }^{-1}$ manure, $200 \mathrm{~kg} \mathrm{ha}^{-1}$ Urea, $100 \mathrm{~kg} \mathrm{ha}^{-1}$ $\mathrm{SP} 18,100 \mathrm{~kg} \mathrm{ha}^{-1} \mathrm{KCl}, \mathrm{P} 3=20$ ton ha ${ }^{-1}$ manure, $200 \mathrm{~kg} \mathrm{ha}^{-1}$ Urea, $100 \mathrm{~kg} \mathrm{ha}^{-1} \mathrm{SP} 18$ and $100 \mathrm{~kg} \mathrm{ha}^{-1} \mathrm{KCl}$.

Table 6. Qualitative character of acclimatized black galingale plant and rhizome from in vitro multiplication.

\begin{tabular}{llllll}
\hline $\begin{array}{l}\text { Fertilizer } \\
\text { Rate }\end{array}$ & $\begin{array}{l}\text { Leaf } \\
\text { color }\end{array}$ & $\begin{array}{l}\text { Presence of } \\
\text { purple streak }\end{array}$ & $\begin{array}{l}\text { Rhizome } \\
\text { skin color }\end{array}$ & $\begin{array}{l}\text { Rhizome } \\
\text { flesh color }\end{array}$ & $\begin{array}{l}\text { Presence of } \\
\text { fleshy root }\end{array}$ \\
\hline P1 & Green & Present & Bright brown & Grayish white & Present \\
P2 & Green & Present & Bright brown & Grayish white & Present \\
P3 & Green & Present & Bright brown & Grayish white & Present \\
\hline
\end{tabular}

\section{CONCLUSION}

Result from in vitro multiplication induction of Kendal accession showed that there was an interaction between plant growth regulator BAP and IAA to the number of shoot, number of leaves, and plantlet height variables. Culture medium with $0 \mathrm{mg}^{-1}$ IAA combined with $6 \mathrm{mg} \mathrm{l}^{-1}$ BAP resulted in the highest number of shoot (3.38 shoot per explant) and tallest plantlet $(2.51 \mathrm{~cm})$, while the highest number of leaves (6.25 leaves per plant) was produced from medium with $6 \mathrm{mg} \mathrm{l}^{-1} \mathrm{BAP}+0.5 \mathrm{mg} \mathrm{l}^{-1}$ IAA. Black galingale plantlet can be acclimatized and produce rhizome that can be used as propagules for black galingale propagation.

\section{ACKNOWLEDGMENTS}

The author would like to thank Tropical Biopharmaca Research Center, Research and Community Services Institution of Bogor Agricultural University (IPB) for funding this research.

\section{CONFLICT OF INTERESTS}

Authors declare that there is no conflict of interest.

\section{REFERENCES}

Adelberg J, Driesse T, Halloran S, Bridges WC. Relationships between nutrients and plant density in liquid media during micropropagation and acclimatization of turmeric. In Vitro Cell Dev Biol, 2013; 49:724-36.

Angel GR, Vimala B, Nambisan B. Phenolic content and antioxidant activity in five underutilized starchy Curcuma species. Int $\mathrm{J}$ Pharmacog Phytochem Res, 2012; 4:69-73.

Atun S, Arianingrum R, Aznan N, Nurestri R. Deskripsi paten: bahan aktif antimutagenik dari rimpang tumbuhan famili Zingiberaceae UNY, Yogyakarta, Indonesia, 2012.

Behera KK, Pani D, Sahoo S. Effect of plant growth regulator on in vitro multiplication of turmeric (Curcuma longa cv. Ranga). J Biol Tech, $2010 ; 1: 16-23$

Behura S, Sahoo S, Srivastava VK. Major constituents in leaf essential oil of Curcuma longa L and Curcuma aromatica Salisb. Curr Sci, 2002; 83:1312-3.
Choudhury D, Ghosal M, Das AP, Mandal P. Development of single node cutting propagation technique and evaluation of antioxidant activity of Curcuma aeruginosa Roxb. rhizome. IJPPS, 2013; 5:227-34.

Chong YH, Khalafalla MM, Bhatt A, Chan LK. The effect of culture system and explant incision in vitro propagation of Curcuma zedoaria Roscoe. J Trop Sci, 2012; 35:863-74.

Cousin M, Adelberg J, Chen F, Rieck J. Antioxidant capacity of fresh and dried rhizoma from four clones of turmeric (Curcuma longa L.) grown in vitro. Indus Crops Prod, 2007; 25:129-35.

Damalas LA. Potential uses of turmeric (Curcuma longa L) product as alternative maeans of pest management in crop production. Plant Omic J, 2011; 4:136-41.

Ding JB, Ding CB, Zhay L, Zhou YH, Yang RW. Relationship among six herbal species (Curcuma) assessed by four isoenzym. Int J Exp Bot, 2011; 80:181-8.

Girija TP, Shree ABR. Comparative anatomical and histochemical characterization of the source plants of the ayurvedic drug Rasna. IJHM, 2014; 2(2):38-46.

Gowda V, Kress WJ, Htun T. Two new species of ginger (Zingiberaceae) from Myanmar. Phytokeys, 2012; 13:5-14.

Harit J, Barapatre A, Prajaprati M, Aadil KR, Senapati S. Antimicrobial activity of rhizome of selected curcuma variety. IJLBPR, $2013 ; 2: 1-7$.

Hazarika BN. Acclimatization of tissue culture plants. Curr Sci, $2003 ; 85: 1704-12$

Hussain A, Qarshi IA, Nazir H, Ullah I. Recent advantages in plant in vitro culture. In Tech Press, Rijeka, Croatia, 2012.

Jadhao AS, Bukhtar AS, and Nagar S. Anatomical studies of Curcuma decipiens DALZ. (Zingiberaceae) from maharashtra state India J Global Biosci, 2015; 4(1):1258-61.

Jan HU, Rabbani MA, Shinwari K. Estimation of genetic variability in turmeric (Curcuma longa L.) germplasm using agromorphological traits. Pak J Bot, 2012; 44:231-8.

Kozai T, Afreen F, Zobayed SMA. Photoautotrophic (sugarfree medium) micropropagation as a new micropagation and transplant production system. Springer, AA Dordrecht, Netherlands, 2005.

Kumar K, Rao IU. Morphophysiological problem in acclimatization of micropagated plant in ex vitro conditions. JOHP, 2012; $2: 271-83$.

Maknoi C, Sirirugsa P, Larsen K. New records of Curcuma longa (Zingiberaceae) in Thailand. Thai Bull, 2005; 33:71-4.

Mohanty S, Reena P, Sikha S, Joshi RK, Subhudhi E, Nayak S. Biochemical and molecular profiling of micropropagated and conventionally grown Kaempferia galanga. Plant Cell Tiss Org Cult, 2011; 106:39-46.

Nasrullah I, Murhandini S, Rahayu WP. Phytochemical study from Curcuma aeruginosa Roxb. rhizome for standardizing traditional medical extract. J Int Environ App Sci, 2010; 5:748-50.

Naz S, Ilyas S, Javad S, Ali A. In vitro clonal multiplication and acclimatization of different varieties of turmeric (Curcuma longa $\mathrm{L}$.). Pak J Bot, 2009; 41(6):2807-16

Nugrahaningtyas KD, Matsjeh S, Wahyuni TD. Isolasi dan identifikasi senyawa flavanoid dalam rimpang temu ireng (Curcuma aeroginosa Roxb). Biofarmasi, 2005; 3:32-8.

Nurcholis W, Khumaida N, Syukur M, Bintang M, Ardyani IDAAC. Phytochemical screening, antioxidant, and cytotoxic activities, in extract of different rhizome part from Curcuma aeruginosa Roxb. Int J Res Ayurveda Pharm, 2015; 6:634-7.

Nurcholis W, Khumaida N, Syukur M, Bintang M. Similarity analysis of 20 promising accesions of Curcuma aeruginosa Roxb. based on rhizome color, extract yield, and phytochemical content. J Agron Indonesia 2016; 44:315-21

Rahayu S, Adil WH. The effect of BAP and thidiazuron on in vitro growth of java turmeric (Curcuma xanthorriza Roxb.). J Agri Biol Sci, $2012 ; 7: 820-4$ 
Ranjini CE, Vijayan KK. Structural characterization of a glukan from the tuber of Curcuma aeruginosa. Indian J Chem, 20015; 44:643-7.

Reanmongkol W, Subhadhirasakul S, Khaisombat N, Fuengnawakit P, Jantasila S, Khamjun A. Investigation the antinociceptive, antipyretic and anti-inflammatory activities of Curcuma aeruginosa Roxb. extract in experimental animals. J Sci Tech, 2006; 28:999-1008.

Rout GR, Samantaray S, Das P, Palai SK. Effect of growth regulator and culture conditions on shoot multiplication and rhizome formation of ginger (Zingiber officinale Rosc.). In vitro Cell Dev Bio Plant, 2001; 37:814-9.

Salvi ND, George L, Susan E. Micropropagation and field evaluation of micropropagated plant of turmeric. Plant Cell Tiss Organ Cult, $2002 ; 68: 143-51$.

Sama AE, Shahba MA, Hughes HG, Abbas MS. Comparative growth analysis and acclimatization of tissue culture derived cocoyam (Xanthosoma sagittifolium L. Schott.) plantlets. AJEA, 2015; 5:94-108.

Setiadi A, Khumaida N, Ardie SW. Diversity of some black turmeric (Curcuma aeruginosa Roxb.) accesions based on morphological characters. J Agron Indonesia, 2017; 45(1):71-8.

Shahihnozzaman M, Ferdous MM, Faruq MO, Azad MAK, Amin MN. Micropagation of black turmeric (Curcuma caesania Roxb.) through in vitro culture of rhizome bud explant. J Cent Europ Agri, 2013; $14: 110-5$

Shukla SK, Shukla S, Koche V, Mishra SK. In vitro propagation of tikhur (Curcuma angustifolia Roxb.): starch yielding plant. Indian J Biotechnol, 2007; 6:274-6.

Srivastava S, Chitranshi N, Srivastava S, Dan M, Rawat AKS, Pushpangadan P. Pharmacognostic evaluation of Curcuma aeruginosa Roxb. Nat Prod Sci, 2006; 12:162-5.

Srivilai J, Khorana N, Waranuch N, Ingkaninan K. Antiandrogenic activity of furanoidiene isolated from Curcuma aeruginosa Roxb extract. Naresuan Univ J, 2011; special issue:33-7.

Sukari MA, Saad S, Lajis N, Rahmani M, Muse R, Yusuf UK, Riyanto S. Chemical constituents and bioactivity of Curcuma aeruginosa Roxb. Nat Prod Sci, 2007; 13:175-9.
Takano I, Yasuda I, Takeya K, Itokawa H. Guianine sesquiterpene lactones from Curcuma aeruginosa. Pergamon, 1995; 40:1197-200.

Tavares WS, Freitas SS, Grazzioti GH, Parente LML, Liao LM, Zanuncio JC. Ar-tumerone from Curcuma longa (Zingiberaceae) rhizomes and effects on Sitophilus zeamais (Coleoptera:Curculioidae) and Spodoptera frugiperda (Lopidoptera: Noctuidae). Indust Crop Prod, 2013; 46:158-64.

Theanphong $\mathrm{O}$, Songsak $\mathrm{T}$, Kirdmanee C. Effect of plant regulators on micropagation of Curcuma aeruginosa Roxb. Thai J Bot, 2010; 2:135-42.

Velayudhan KC, Dikshit N, Nizar NA. Ethnobotany of turmeric (Curcuma longa L.). Indian J Trad Know, 2012; 11:607-14.

Yaacob JS, Saleh A, Elias H, Abdullah S, Noraini M, Mohamed N. In vitro regeneration and acclimatization protokols of selected ornamental plants. Sains Malaysiana, 2014; 43:715-22.

Yahya MF, Hassan NH, Abdullah N, Rahman SSA, Ismail H, Abdullah MZ, Ariff M, Ngah ML, Koter R, Khalid R, Abdullah R, Zakaria N. Acclimatization of Euricoma longifolia (Tongkat Ali) plantlet to ex vitro conditions. JTRSS, 2015; 3:129-31.

How to cite this article:

Khumaida N, Ardie SW, Setiadi A, Artiningsih LN. In vitro multiplication and acclimatization of black galingale (Curcuma Aeruginosa Roxb.). J Appl Pharm Sci, 2019; 9(04):110-116. 